Sheffield Hallam University
Centre for

Regional Economic

and Social Research

\title{
Citizen engagement in local energy decision-making: literature and policy background
}

\section{June 2020}
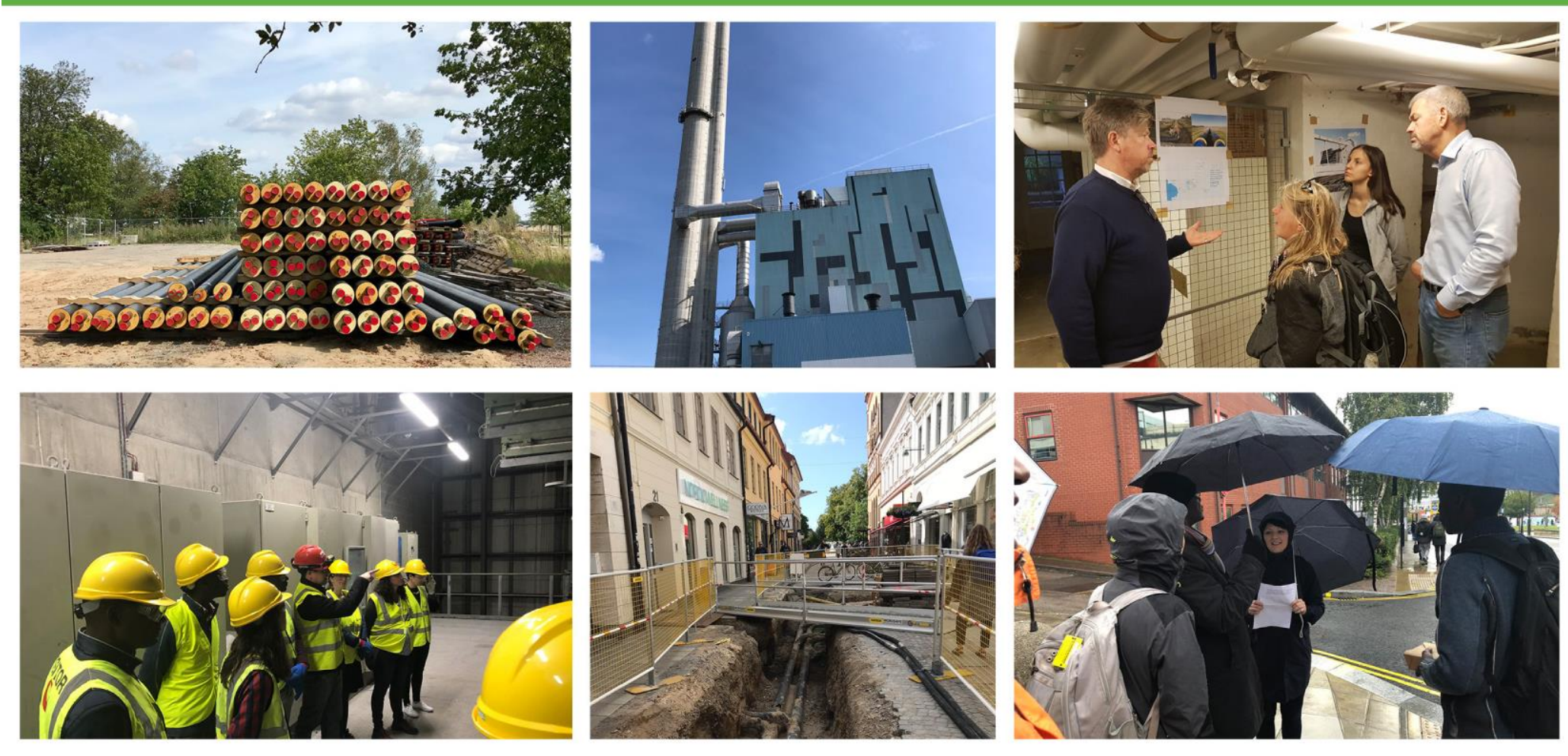


\section{Citizen engagement in local energy decision-making: literature and policy background}

\section{Author(s):}

Professor Richard Bull, School of Architecture, Design and Built Environment. Nottingham Trent University. richard.bull@ntu.ac.uk

Dr. Will Eadson, Centre for Regional, Economic and Social Research. Sheffield Hallam University. w.eadson@shu.ac.uk

June 2020

DOI: 10.7190/cresr.2020.8937358309 


\section{Contents}

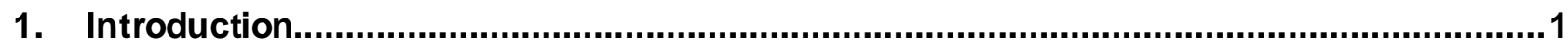

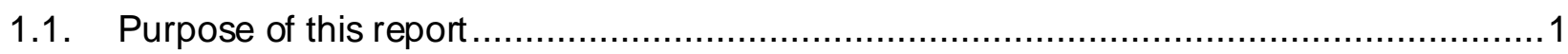

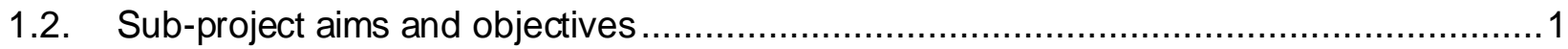

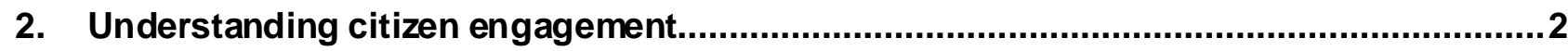

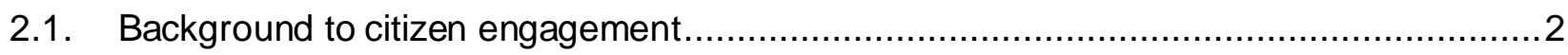

2.2. Citizen Engagement, Energy and Behaviour Change ......................................... 4

2.3. Contemporary debates in Citizen Engagement ................................................... 5

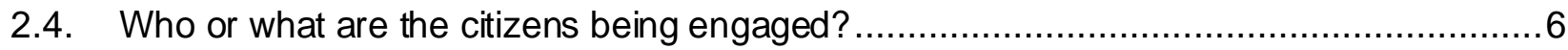

3. Existing policy for citizen engagement in Sweden and the UK.....................................

3.1. Wider policy context: centralisation and marketisation ........................................

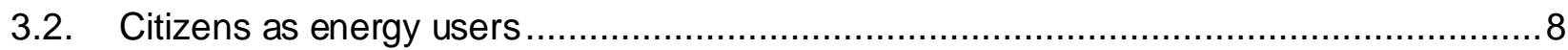

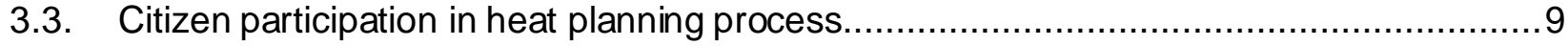

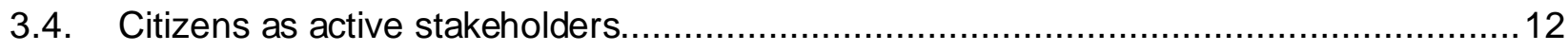

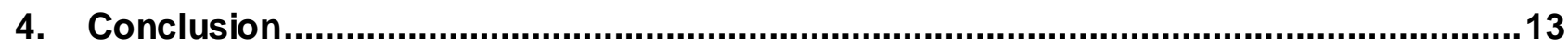

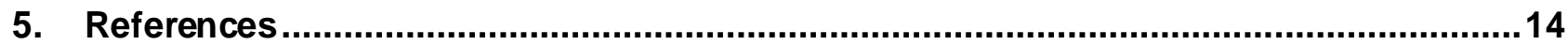




\section{Introduction}

\subsection{Purpose of this report}

This report is the first output of a sub-project within the Walking with Energy project. The sub-project focuses on citizen involvement in heat infrastructure decision-making. The report presents the opportunities and barriers for citizen engagement in heat infrastructure decision-making and reflects on the UK and Swedish policy context. It provides an introduction to the literature on citizen engagement and examines the existing policy and practice in Sweden and the UK relating to citizen participation with energy systems, with specific reference to heat networks.

Walking with Energy, as outlined in Ambrose (2020) is based on two key premises: 1) energy invisibility is hindering responsible energy behaviours and energy citizenship and, 2) citizen engagement is an important vehicle for addressing that decline in literacy. In line with the aims for this sub-project this report presents an introduction to the literature on citizen engagement before exploring the policy context of heat networks. We then briefly present the next steps of the research.

\subsection{Sub-project aims and objectives}

The aim of this sub-project is to supplement the wider Walking with Energy project by seeking to better understand the opportunities and barriers for citizen engagement in heat infrastructure decision-making.

The sub-questions for the research are as follows:

- What is the national policy framework for engaging citizens on decision-making for heat infrastructure?

- To what extent and how do citizens and citizen-focused stakeholders (e.g. employees, community groups, and other representative bodies) participate in local heat infrastructure decision-making, to enable citizen involvement and representation in these processes.

- What strategies to heat infrastructure developers /operators use to engage with these stakeholders? And what are their motivations for doing so?

- How do different levels and ways of participating in decision-making impact on environmental (or energy/waste?) behaviours for individuals?

This report provides background academic literature and policy review to inform later empirical fieldwork and written outputs. 


\section{Understanding citizen engagement}

\subsection{Background to citizen engagement}

Citizen engagement has its theoretical roots in deliberative democracy. John Dryzek (2000) defined deliberation as a unique communication process in which people are open to changing their views through a process that involves "persuasion rather than coercion, manipulation or deception" (Dryzek, 2000: 1). He believed that deliberative, or discursive, processes have the potential to 'deepen' democracy by strengthening the involvement of citizens. Underpinning this is the importance of language. Building on Jurgen Habermas' theories of communicative competence Thomas Webler defined participation as the "interaction among individuals through the medium of language" (Webler, 1995: 40). Habermas (1979) argues that any communication between two individuals would fail without cooperation. An individual's ability to use language to create understanding and consensus is referred to as 'communicative competence'.

Dryzek (1990) conceived of his theory of discursive democracy in the context of the need to respond to global environmental problems, and in particular, how the nature of risk changed. ${ }^{1}$ The framing of risk as a negotiated concept underpinned the transformation of risk communication to incorporate lay and expert views (Renn, 1992; Jasanoff, 1993) which laid the foundations for much of the thinking around the need for engagement. Fischhoff (1995) details the evolution in risk communication from what is known as the technocrat view ("All we have to do is get the numbers right and tell them") to an analytic-deliberative model that embraces partnership and recognises the complexity of two-way communication between experts and the public (Stern and Fineberg 1996). At the heart of this evolution in risk communication was the increasing uncertainty and lack of trust amongst the public in decision-makers, institutions, and experts (Irwin, 1995; Wynne, 1996; Pellizzoni, 2004). Citizen engagement in decisionmaking was viewed as a critical step in countering uncertainty.

Despite understanding that citizen engagement is important in making policy decisions, engagement and/or participation take a wide range of forms, some of which are more empowering and participatory than others. Viewed as a seminal model of participation, Arnstein's (1969) ladder of participation defined practical steps to empowerment (Figure 1). She advanced the normative and ethical argument that citizen involvement is an improved and more just way of governing society. However, her ultimate goal went further in that she conceived of participation as potentially about empowerment, providing for a redistribution of power to those traditionally excluded from the political and economic processes whilst creating a route for citizens to participate in social reform (Arnstein, 1969).

${ }^{1}$ For many risk has become something that is socially constructed, a fluid and relative concept rather than an objective, measurable one (Wynne 1992; Irwin 1995; Wynne 1996; Klinke and Renn, 2002). 


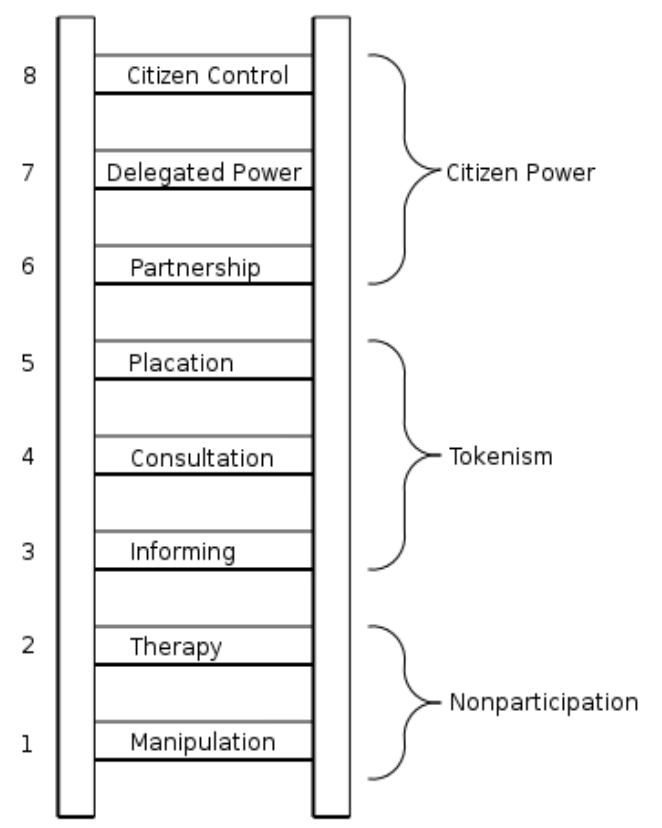

At the bottom was information provision, a predominantly one-way form of communication, but arguably essential to informing the higher steps. Moving up the steps, consultation is usually conceived as a relatively passive process asking for people's opinions but not necessarily engaging them in debate. Surveys, for example, are a standard method of consultation. Participation is normally used to refer to processes, which allow people to participate in a decision by putting forward their views verbally whereas engagement goes further, suggesting an innovative and interactive, two-way process of discussion and dialogue (i.e. deliberation) to ensure that people's views inform a decision, alongside those of the expert and/or decision-maker. This is still one-step removed, however, from Arnstein's top step of her ladder that defines empowerment as people taking control of decisions and their implementation.

Engagement methods seek to optimise opportunities for dialogue between experts and public. They include community panels and advisory committees, citizen's juries, focus groups and consensus panels. Increasingly we have seen experimentation with such methods in the siting of controversial facilities such as hazardous waste facilities (Lidskog, 1997), transport planning (Bickerstaff and Walker, 2005), air quality management (Petts and Brooks, 2006), and the siting of municipal waste facilities (Petts 1995;). More recently opportunities for wider participation and engagement has been explored both in the local and regional examples of smart cities (Bull et al., 2019) and buildings (Bull and Janda, 2018) and of course the climate assembly in which over 100 participants are involved in citizen' juries to consider options for how the UK can meet the Government's legally binding target to reduce greenhouse gas emissions to net zero by 2050 (https://www.climateassembly.uk).

Sovocool notes three key benefits of citizen engagement (2014): First, democracy is increased as all citizens have a right to participate and be represented in environmental decision making; second, non-experts are often more attuned to the ethical issues of a situation; and third, greater acceptance can often be achieved by involving all those affected by the particular situation. A fourth benefit that is of ten overlooked is that processes of public engagement can create ideal conditions for social learning which can lead to varying degrees of behaviour change (Bull et al., 2008). 
Principles of effective citizen engagement are based on Habermasian principles of ideal speech and communicative competence to measure the effectiveness of deliberative processes (Webler, 1995; Webler and Tuler, 2000; Diduck and Mitchell, 2003; Petts, 2004). Two principles underpin the criteria: fairness and competence. Fairness refers to the opportunity for all interested or affected parties to assume a legitimate role in the decision-making process, for example, the initial opportunity to attend the meeting, to be able to initiate discourse and actually participate in the discussion, and finally to participate in the decision-making process. Competence is the degree to which processes reach the best decision possible given what is reasonably knowable under present conditions. For example, there is a need to ensure access to the best available information. In the case of a group discussing energy from waste that could mean the opportunity to hear from the 'experts' in the relevant waste technology (Webler and Tuler, 2000).

\subsection{Citizen Engagement, Energy and Behaviour Change}

Fundamental to the wider Walking with Energy project is that engagement affects behaviour, or learning in some capacity. Bull et al (2008) found that deliberative citizen engagement processes demonstrated potential for a legacy of social learning and behaviour change, as Webler et al (1995: 444) hoped: "When citizens become involved in working out a mutually acceptable solution to a project or problem that affects their community and their personal lives, they mature into responsible democratic citizens and reaffirm democracy."This approach underpins much of the thinking for the Walking with Energy approach, as outlined in Ambrose (2020), particularly as it moves away from a purely individualistic focus to explore the social dynamics of participation and engagement. Much research has been done on the broad theme of behaviour change which can be understood through a range of approaches and disciplines ranging from environmental psychology, social science and economics, educational science or critical theory. A comprehensive review of the evidence on consumer behaviour and behaviour was carried out by Tim Jackson (2005). However, this review pre-dated a significant shift in the debate between individualistic and predominantly environmental psychological approaches, which all broadly sat under the assumption of a particular 'information-deficit' or rational approach to behaviour change - if 'they' have the right information 'they' will change behaviour. Underpinning these approaches are often a range of environmental psychology models that attempt to unpick an individual's attitudes $(A)$, behaviour (B) and context $(C)$ in relation to energy (Stern, 2000). This 'ABC' approach to behaviour change has been extensively criticised by academics (Shove, 2010, Hargreaves, 2011) who argue that behaviour is more complex and the result of deeply engrained social practices, values and institutional and organisational barriers that undermine or limit the impact an individual may have. Exhorting us to an alternative, more complex approach that sidesteps the polarised debate between the $A B C$ versus social practice school of thought, Owens and Driffill (2008) argue for a reframing of the relationships between those responsible for energy management and those using the energy via "a more interactive, deliberative communication between decision-makers, technical experts, other stakeholders and the public" (2208: 4414). In a comprehensive review of over twenty energy and behaviour change interventions in the workplace Staddon et al(2016) note that the most successful initiatives had a combination of technological automation and 'enablement' - that is opportunities for people to move beyond education and training and change the relationships of the relevant actors and a shift in levels of individual control and responsibility. These principles are key as we explore our changing relationship to energy. 


\subsection{Contemporary debates in Citizen Engagement}

Contemporary debates in the space of citizen engagement have started to move beyond evaluating and exploring single 'one-off' or stand-alone examples of participation to considering both the systemic context of participation (Chilvers and Longhurst, 2016) and also energy democracy and community dimensions to engagement (van Veelen and Eadson, 2020). Questions have also been asked of the validity of Arnstein's ladder and the dismissal of any engagement that does not result in empowerment (Zakhour, 2020).

Chilvers and Longhurst (2016) note four emerging themes around citizen en gagement. Firstly, the need to view participation through a systemic lens and not isolate individual acts of engagement; second, this perspective widens out the forms of what participation may look like; third, this changes the actor dynamics with participation and how people are enrolled. Finally, it stresses the importance of political or system change. Practically this manifests itself, for example, in how the public are framed in the process of engagement. In mainstream approaches to engagement, as outlined above, the public are a defined group who are 'engaged' with a specific purpose. In this constructivist approach it is argued that the 'public' are not a static group who are engaged, nor is engagement a neatly defined process, but instead an emerging and dynamic phenomenon. ${ }^{2}$

Alongside these emerging themes Chilvers and Longhurst (2016) note four approaches to engagement:

1. Deliberative democracy: citizens who are engaged in a deliberative way and encouraged to contribute via fora or surveys in order to inform the decisions of others.

2. Practice theory: this approach explores the role of citizens as consumers in the energy system.

3. 'Grassroots' innovation: typically, formal civil society groups who are proactive in contributing to local policy contexts rather than simply responding to being 'engaged'.

4. Social movement theory: these are actors or groups engaged in more contentious politics.

For Chilvers and Longhurst (2016) then the term public engagement encompasses all of these diverse forms of public and civil society participation in sustainability transitions. Two key questions underpin their analysis of four cases which are very relevant to 'Walking with Energy'. Firstly, what forms of enrolment, mediation and exclusion are involved? Second, what are the productive dimensions and effects of the participatory collective?

In their conclusions they note firstly that engagement rarely falls into distinct or neat categories. A particular intervention may exhibit features across more than one category. Second, there is a challenge regarding how the actors involved are able to reflect on their own experience of being engaged. For Walking with Energy this will be an interesting proposition as the participants are not being asked to decide on something, or feed into a discrete process. Rather, participants are being asked to reflect on their role within the energy system.

Zakhour (2020) continues this critical tone around public engagement, noting that Arnstein's ladder, that underpins many of the assumptions around engagement

\footnotetext{
${ }^{2}$ Reflections on the nature of the 'public' will be developed at a later date.
} 
implied a simplistic and normative tone that the destination was always empowerment, and that there is a simple linear process to achieve. Zakhour notes that reality is messy and there is a blurring over what constitutes successful engagement and who defines that success.

One final example of engagement, a fifth strand added to the list above, must be mentioned and that is community energy. Whereas typically, as noted above, public engagement is viewed as a precursor to an event, decision or process, community energy schemes embody the role of the citizen in the scheme. Van Veelen and Eadson (2019: 3) define community energy broadly as 'energy generation, purchase and/or conservation initiatives owned or operated by, and benefiting, communities of place or of interest." Such schemes are heralded in as decentralised approaches to corporate or public sector owned schemes. Community energy also does not imply a homogenous approach to such schemes. Creamer et al (2019) note the range of approaches that can include schemes that deal with energy generation, how it distributed and how it is sold.

Walking with Energy is situated in a relatively unique space as it does not seek to 'do participation' to anyone with the purpose of changing behaviour, nor are explicit ownership models of energy being discussed. However, as the notion of energy invisibility is explored and interrogated via the citizens and citizen-focused stakeholders, it is important to consider the different facets and scales of engagement citizens have, especially if the participants are those who actually receive their energy via the district heating scheme.

\subsection{Who or what are the citizens being engaged?}

An important issue to consider is not just how to engage with, but also who or what consists of legitimate publics to engage with. In political theory, publics have conventionally been defined as groups of people relevant to particular policies or debates. For instance, May (1991: 191) describes publics as:

"...identifiable groupings who have more than a passing interest in a given issue debate or are actively involved in an issue debate... Publics may take the form of professional associations, producer groups, consumergroups, trade groups, public interest groups, neighborhood groups, or other groups surrounding common issue interests."

Contemporary debates emphasise that publics are not 'out there' to be discovered, but rather consist of a range of different interests and groups that might vary depending on the subject under discussion (Barry, 2013). Publics are constructed by material and discursive processes in relation to particular (sets of) issues (Chilvers and Kearnes, 2019). This includes decision to be made about who or what matters, which in turn highlights power inequalities about how such decisions are shaped: which publics are visible and to who?

In addition to changing understanding of publics as constructed entities, increasing attention has been given to the important role materiality plays in shaping and constructing publics. Marres and Lazaun (2011) argue that it is necessary to examine how material settings, devices and objects shape how publics are constructed. This way of thinking also changes how we think about where engagement is enacted. Thinking about participation as being embedded in the material world draws attention to everyday engagement with objects, technologies and landscapes. Thinking about materiality is important for our project: energy systems are inherently (socio)-material and they shape and are shaped by the landscapes (Castan Broto, 2019) and everyday experiences of people in contemporary societies. 


\section{Existing policy for citizen engagement in Sweden and the UK}

The proceeding sections follow on from the review of existing academic literature on participation in energy systems to examine existing policy and practice in Sweden and the UK relating to citizen participation with energy systems, with specific reference to heat networks.

Understanding the role of policy in citizen engagement with heat systems requires consideration of different governmental organisations operating across different geographic spheres. This includes national and local government as well as intermediary and non-governmental regulatory bodies such as market regulators (the Office for Gas and Electricity Markets (Ofgem) in the UK, the Energy Markets Inspectorate (Ei) in Sweden) and city-regional or regional governmental organisations. These each have a range of different responsibilities and resources relating to heat policy. A review of policy in Sweden and the UK reveals three main ways that existing policy and energy system operators seek to engage citizens:

1. Citizens as energy users: protections and engagement with decision-making about pricing and terms of service.

2. Citizens as consultees in planning and development process.

3. Citizens as stakeholders (including beyond those who use the energy produced): participation in decisions about on-going governance or as owners of projects.

These different roles suggest differing levels of engagement, which can be broadly mapped onto Arnstein's ladder of participation: consumers right at the bottom, moving up to ownership at the top. Each of these also produces questions about which publics 'matter' and are being produced by processes of engagement. Even within these roles existing practice and possibilities for active participation vary. These three approaches are considered in turn, but first we provide a short review of the wider policy context for energy systems in Sweden and the UK.

\subsection{Wider policy context: centralisation and marketisation}

Any investigation into citizen participation in energy systems must be set in the context of changes to energy system governance over the last 30 years, across the global north. This period saw a move away from state ownership of energy production, distribution and supply to increasing focus on creation and maintenance of competitive energy markets. This has been overseen at an international level by organisations such as the European Commission, who have implemented programmes to privatise and 'liberalise' energy systems (Helm, 2003; Jamasb and Pollitt, 2005; Eadson and Foden, 2019). Energy markets are now the predominant means of organising production, distribution and supply, even where state bodies retain ownership of some institutions. 
Arguably though, these markets have not functioned as intended. In the UK, energy companies are not highly trusted by energy users (Yougov, 2014), on the back of various issues relating to market abuse, lack of transparency, complex tariff structures and perceived overcharging (Ofgem, 2014; Eadson and Foden, 2019). There has also been weak competition between suppliers partly as a legacy of a regionally organised supply system. This further contributes to low levels of switching between energy providers (Ofgem, 2014). Entry barriers for new suppliers are high (Koh and Goucher, 2014), reducing scope for increased competition. In the UK a small number of large multi-national companies have dominated energy supply although there has been an increase in smaller suppliers in recent years. In $2010,99 \%$ of the domestic energy supply market was shared between the so-called 'big six' energy companies; by the end of 2019 this had fallen to $70 \%$, with the remainder largely shared between a wide range of medium-sized and small suppliers.

District heating remains a very small proportion of overall heat supply: less than $2 \%$ of heat supply comes from district heating (Ambrose et al., 2016). We have not found data specifying ownership of district heating systems across the UK. However, in broad terms, district heating systems set up prior to 1990 were local authority owned. Over the last 30 years many of these have been leased out or transferred to private sector organisations, and new systems have tended to be developed as joint ventures between local authorities and private sector organisations, or in some cases as entirely private sector-led, with private sector organisations managing supply arrangements. Some examples of alternative, non-profit ownership structures do exist - such as in Nottingham, where the district heating system is managed by a partnership of local authority and voluntary sector organisations.

In Sweden three large companies account for $46 \%$ of the electricity market. The natural gas market is much smaller than in the UK, with only around 30 local authority areas connected to a gas grid. By contrast, over half of heat supply is provided by district heating (55\% in 2014; Werner, 2017). More broadly, Swedish municipalities have traditionally played key roles as suppliers of gas, electricity and district heating to households. Deregulation of the electricity market in 1996 led to privatisation of many municipal energy companies (Wretling et al., 2018) and correspondingly ownership of district heating systems in Sweden has also changed over time. Whereas in 1990 all systems were owned by municipalities, the proportion of district heat sales from municipally owned networks had fallen to $60 \%$ (ibid.).

However, regardless of energy source, energy users remain distanced from the technicalities of where their gas and electricity comes from, in part reflecting the predominance of centralised energy supply (Soutar and Mitchell, 2018). Energy markets deliver relatively homogeneous goods and services: heat or electricity as an output is more or less the same whatever the retail supplier. This in turn makes energy difficult to marketise as a consumer good (Giulietti et al., 2005). Private rather than public ownership of networks (and associated policy discourses - see Eadson and Foden, 2019) also potentially distances energy users from energy systems, fuelling 'energy invisibility' (Ambrose, 2020): users are cast as energy 'consumers' rather than active stakeholders in the energy system.

This brief overview of energy markets in the UK and Sweden sets the scene for more specific consideration of ways that citizens engage with heat networks, beginning where the market overview left off: citizens as energy users/consumers.

\subsection{Citizens as energy users}

Right at the bottom of the participation ladder, an important form of citizen engagement with heat networks is as users of heat produced and distributed through the network. The question is how far citizens engaging with heat networks purely in their role as 
energy users can lead to deeper engagement with the energy system: something that the wider WWE project is seeking explore. Here we consider existing policy.

Because heat networks often operate as de facto monopoly suppliers for residents of buildings supplied by district heating, these residents are au tomatically 'engaged' with the system in a basic sense but also the lack of alternatives and automatic enrolment (for many) can limit levels of engagement with systems.

Although specific mechanisms vary across networks, price-setting is a technical process and does not involve citizens in setting prices. More broadly, in the UK there is no existing regulatory framework for consumer protection in heat networks. Qualitative research by BEIS (2018) found that consumer protection practices varied across heat networks. Private sector operators focused on a relatively narrow set of obligations around contractual arrangements between landlords, developers and users. Public sector operators were more likely to take a holistic view of their obligation to users, however, in part because they were often also users' landlords as well as energy supplier (ibid.). Where heat users take heat from their landlords, this offers additional engagement mechanisms, for instance through landlord communications with individual tenants, Tenant Unions, Tenant Management Organisations and other forms of tenant-led organisations. Overall, however, district heat users have little awareness of their rights as consumers (ibid.). In response to these challenges, the Competition and Markets Authority (CMA, 2018) recommended establishment of a formal consumer protection body for heat networks, but this has not yet been implemented. A voluntary consumer protection organisation was set up in 2015, named Heat Trust. Members agree to abide by a code of conduct which Heat Trust says is compliant with wider UK electricity and gas market regulation. As of 2018 its members covered around 10\% of total heat network users (Heat Trust, 2018).

Despite a much longer history of widespread connection to District Heating, liberalisation of energy markets in Sweden has produced a similar regulatory picture to that in the UK. Heat networks are considered to be market providers of energy and as such pricing is not directly regulated (IEA, 2019). However, following steep price rises over the 1990s and 2000s the District Heating Act 2008 introduced the 'price dialogue' mechanism as part of measures to improve transparency over pricing (ibid.).

An independent not-for-profit organisation was established in 2011, called Prisdialogen ('Price Dialogue'). Prisdialogen assesses district heat prices and works to improve transparency in accounting. Local agreements (covering $72 \%$ of $\mathrm{DH}$ supply in 2017) set out principles for any price changes. This process has been successful in improving transparency and consumer trust (IEA, 2019). Similar principles are in place in other countries too. For instance Heat and the City (2019) note how in the Netherlands introduction of a simple, transparent accounting method for heat networks helped customers to better understand pricing decisions, revealing how in most cases returns for suppliers were quite low - in turn increasing trust in suppliers.

Such mechanisms offer very limited potential for more engaged participation in energy system decision-making. And more broadly, viewing energy users through a market prism - as consumers of a commodity - provides a very narrow framing for user participation. We now move on to consider the role of citizens as active participants in the development process, considering their potential as stakeholders who shape decision-making about whether and how to develop heat networks in particular places.

\subsection{Citizen participation in heat planning process}

Largely speaking, citizen participation in heat network planning and local energy planning in general in Sweden and the UK has been limited to statutory consultation regarding specific planned developments. When considering planning in the UK, it is 
important to differentiate between England and Wales, which have broadly the same planning system, and Scotland, which has devolved powers for planning. Here we focus mostly on England and Wales within the UK, but with a short summary of differences in Scotland.

The planning system in England and Wales is not a strong mechanism for delivering local renewable energy or for building citizen engagement in local renewable energy. An RTPI research report on Planning for a Smart Energy Future (2019) reported that:

At present, with a few exceptions, planning policy in England and progress on the ground lags behind the opportunities offered by smart energy to support clean growth and mitigate climate change. Notable strides have been taken to cut emissions using existing planning powers and tools. However, based on current progress, the pace of change is not sufficient to harness the ambitions and benefits set out in the Clean Growth Strategy, or to meet the UKs legal commitments to decarbonise. (p.6)

There are various issues behind this statement, as follows.

First, local plans have not tended to be strong mechanisms for community engagement in England and Wales (see Baker et al., 2007 and Brownill and Carpenter, 2017). Much of the engagement is through statutory consultation, rather than genuine participation in planning processes.

Second, since 2010 development plan policies have been dominated by the overriding emphasis on facilitating new house building, particularly after the 2012 National Planning Policy Framework (NPPF), which required local authorities to identify a 5year housing supply of deliverable housing sites. The NPPF also weakened the ability of local authorities to ask for Section 106 (planning gain) developer contributions because emphasis was placed on developer feasibility. The NPPF was updated in 2018 and 2019 and slightly reduced the pro-development emphasis (e.g. through a greater emphasis on design control and relaxing some elements of the 5-year housing land supply and viability requirements). In principle the revised NPPF might allow local authorities to be more proactive in strategic planning, and perhaps with more emphasis on climate proofing. However, there has been limited change in relation to renewable energy in the 2018/2019 revised NPPFs. The overriding emphasis is to deliver housing with limited emphasis on energy efficiency or renewable energy.

Third, after 2010 national planning policy weakened previous commitments to delivering renewable energy through local planning (e.g. as set out in PPS22 Renewable Energy (2004) which included local targets for onsite renewable and broad support for delivering renewable energy through local plans. PPS22 was replaced by the NPPF. See also the abolition of the Code for Sustainable Homes). The NPPF (Paragraph 97) requires local authorities to consider suitable areas for renewable and low carbon energy sources. It also states that Councils should consider joint approaches to carrying out local renewable/decentralised energy studies which will help identify areas where there are the greatest opportunities and support the determination of local renewable energy targets. However, these are only suggestions and national planning policy does not include prescriptive frameworks or targets for renewable energy generation.

Fourth, although less directly relevant to heat network development, since 2010 local authority and citizen engagement with planning for renewable energy has been limited by the presumption against onshore wind (2016 - lifted in 2020) and the scaling back of Feed-in-Tariffs and other subsidies. In general, local authorities are not particularly proactive on local energy generation, limiting the scope for using development plans in that way (see Cowell et al., 2017). 


\section{Neighbourhood planning}

The introduction of neighbourhood planning through the UK government's Localism Act in 2011 has created scope for more active citizen engagement in planning. Neighbourhood plans cover small community areas and are prepared by neighbourhood planning fora rather than local authorities. Plans have to be agreed through community referenda. In principle neighbourhood plans could be a useful vehicle for renewable energy projects (CSE, 2015;2020; Shared Assets, 2019).

However, there has been no research on the inclusion of energy policies within neighbourhood plans. What is known is that neighbourhood planning is underfunded, it relies on voluntary commitment, neighbourhood planning areas tend to be in more affluent communities (neighbourhood planning areas are self-selecting) and the overriding emphasis tends to be on house building (Bailey and Pill, 2015; Parker, 2017), which was arguably always the intention. Inch (2012) for example shows how neighbourhood planning was intended to help build support for new house building (or reduce resistance) in areas that might otherwise have resisted new residential development.

There is a separate planning system in England, Wales, Scotland and Northern Ireland. Wales and Northern Ireland are similar to England in terms of community engagement. However, the system of community planning in Scotland has stronger institutional mechanisms for community engagement in and around planning. The Scottish Government's Community Empowerment Act 2015 mandates that planning must be carried out in partnership with community organisations through a Community Planning Partnership. Relating more directly to energy, the Scottish Government, via intermediary body Local Energy Scotland, have trialled community-led local energy plans in four areas. Under this scheme energy plans for each area are coordinated by a local steering group of community representatives and representatives from the local authority, Home Energy Scotland and Local Energy Scotland (Local Energy Scotland, 2019). However, barriers to community engagement in the planning system remain, as shown by Scottish Government-commissioned research, which found the following barriers:

- there is a lack of trust, respect and confidence in the system

- the system is not considered to be fair and equitable

- there is a gap between the rhetoric of community empowerment and communities' experience of trying to influence the planning system

- $\quad$ there is a lack of clarity about the purpose of engagement

- $\quad$ experience suggests that engagement rarely changes planning outcomes

- planning is complex and some tensions are inevitable

- the planning system should recognise the rights of all parties but also their responsibilities.

In general terms, across the UK the scaling back of subsidies and support since 2010 has limited the scope for progressing local low carbon energy through the planning system (Cowell et al., 2017).

\section{Sweden}

In Sweden, local authorities are required to produce a local energy plan covering supply, distribution and use of energy, introduced through the Municipal Energy Planning Act (1977). The later Planning and Building Act (2010) mandated 'stakeholder participation' in decision-making: 
The idea is to involve all participants, combining influence, inclusiveness, and deliberation, embracing democratic values such as citizens'rights to information, justice, and participation. The deliberative agenda has achieved a privileged position; even though several examples exist on how difficult it is to accomplish these normative ideals. (Gustafsson, Ivner and Palm, 2015 p.207)

However, there remain concerns that municipal planners continue to be highly influential over problem definition, presentation of options, and deciding which participants are engaged. Further, Gustafsson, Ivner and Palm (ibid.) argue that the Act on Municipal Energy Planning (2015) has in comparison with the Planning and Building Act narrowed participation, concentrating instead on a smaller range of actors, focusing on: municipalities, large stakeholder organisations, and energy producers. Gustafsson, Ivner and Palm (ibid.) also argue that weak implementation of the Act means uneven compliance across local authorities.

\subsection{Citizens as active stakeholders}

A third mode of engagement - more involved than simply consulting with citizens (no matter how participatory) - is for citizens to actively participate in on-going decisionmaking about heat as formal stakeholders (for instance through community representatives on heat supplier boards). At present there are no policy levers in place to ensure this happens in the UK or Sweden.

Energy market liberalisation over the past 30 years in both countries has weakened the link between citizens and district heat projects. In Sweden and the UK, the large majority of heat networks were municipally owned up until the 1990s. This provided an - albeit imperfect - degree of democratic accountability for heat networks: elected officials, with a statutory responsibility to protect the wellbeing of local residents were at least in theory democratically accountable for the performance of heat networks. Energy policy in Sweden and the UK has gradually eroded this democratic link however, with heat network development and operations increasingly conducted by private sector organisations, albeit often in partnership with, or under contracts with local authorities (Palm, 2007; Rutherford, 2014; Hawkey, Webb and Winskel, 2013). As noted above, where district heating networks are operated or at least contracted by social housing organisations there are potentially more opportunit ies for direct resident engagement in decision-making (BEIS, 2018).

The possibilities for more democratic citizen engagement in governance processes through municipal and third sector partnerships will be examined in our empirical investigation.

A more direct level of participation might be possible through community or resident ownership of district heating networks. Such projects are relatively rare in Sweden and the UK, at least in part due to the capital costs involved in setting up. The UK government has published guidance for citizen groups seeking to set up communityled heat projects (DECC, 2016). However, there is little existing evidence on how these have fared in practice: something that will also be explored in our empirical study. 


\section{Conclusion}

This short paper set out to review the lie of the land in terms of both what we mean by citizen engagement, and how and to what extent we are seeing citizen-focused stakeholders participating in local heat infrastructure decision-making. The benefits of engagement are clearly seen in the literature but there is currently no clear and consistent policy led implementation of stakeholder engagement policy, especially for heat infrastructure. Further research is required to explore what strategies heat inf rastructure developers and operators use to engage with their stakeholders and how do these different levels and ways of participating in decision-making impact on the pro-environmental behaviours of these stakeholders (both citizens, employees and policy makers). This will take the form of three case comparative case studies, Nottingham and Sheffield in the UK, and Malmo in Sweden. Alongside detailed desktop and background studies of these cases interviews are planned with the key stakeholders in each site and municipal context to inform our findings and the wider project. 


\section{References}

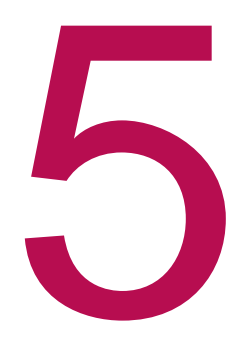

Ambrose, A., Eadson, W. and Pinder, J. (2016) The role of actor-networks in the early stage mobilisation of low carbon heat networks. Energy Policy, 96, pp. 144-152.

Ambrose, A. (2020) Walking with Energy: Challenging energy invisibility and connecting citizens with energy futures through participatory research. Futures, 117.

Arnstein, S. (1969) A Ladder of Citizen Participation. Journal of the American Institute of Planners, 35, pp. 216-224.

Bailey, N. and Pill, M. (2015) Can the State Empower Communities through Localism? An Evaluation of Recent Approaches to Neighbourhood Governance in England. Environment and Planning C: Government and Policy, 33 (2), pp. 289-304. DOI: $10.1068 / \mathrm{c} 12331 \mathrm{r}$.

Baker, M., Coaffee, J. and Sherriff, G. (2007) Achieving successful participation in the new UK spatial planning system. Planning Practice and Research, 22 (1), pp. 79-93.

Barnett, C. (2008) Convening publics: the parasitical spaces of public action. In: K Cox, M Low and J Robinson (eds) The handbook of political geography. London: Sage.

Barry, A. (2013) Material Politics. Disputes along the pipeline. Chichester: Wiley.

Brownill, S., and Carpenter, J. (2007) Increasing participation in planning: Emergent experiences of the reformed planning system. Planning Practice and Research, 22 (4), pp. $619-634$

Bull, R. and Janda, K. (2018) Beyond feedback: introducing the 'participation gap' in organisational energy management. Building Research and Information, 46 (3), pp. 200-215.

Bull, R., Dooley, K. and Mazhar, M. (2019) The Crucial Role of Citizen Involvement, In: WJ Nuttall, DV Gibson, A Ibarra-Yunez and D Trzmielak (Eds.) Smart City Development and Operation. Energy and Mobility in Smart Cities. Institution of Civil Engineers Publishing.

Cástan Broto, V. (2019) Urban Energy Landscapes. Cambridge: Cambridge University Press.

Chilvers, J. and Kearnes, M. (2020) Remaking Participation in Science and Democracy. Science, Technology and Human Values, 45 (3), pp. 347-380. 
Chilvers, J. and Longhurst, N. (2016) Participation in Transition(s): Reconceiving Public Engagements in Energy Transitions as Co-Produced, Emergent and Diverse. Journal of Environmental Policy and Planning, 18 (5), pp. 585-607. DOI: 10.1080/1523908X.2015.1110483.

Competition and Market Authority (CMA) (2018) Heat networks market study: final report. CMA.

https://assets.publishing.service.gov.uk/media/5b55965740f0b6338218d6a4/heat ne tworks final report.pdf

Cowell, R., Ellis, G., Sherry-Brennan F., Strachan, P.A. and Toke, D. (2017) Rescaling the Governance of Renewable Energy: Lessons from the UK Devolution Experience. Journal of Environmental Policy \& Planning, 19 (5), pp. 480-502. DOI: 10.1080/1523908X.2015.1008437.

Creamer, E., Eadson, W., Van Veelen, B., Pinker, A., Tingey, M., Braunholtz-Speight, T., Markantoni, M., Foden, M. and Lacey-Barnacle, M. (2018) Community energy: Entanglements of community, state, and private sector. Geography Compass, 12 (7), pp. 1-16. Available at: https://doi.org/10.1111/gec3.12378

Diduck, A. and Mitchell, B. (2003) Learning, Public Involvement and Environmental Assessment: A Canadian Case Study. Journal of Environmental Assessment Policy and Management, 5 (3), pp. 339-364.

Dryzek, J. S. (1990) Discursive Democracy. Cambridge: Cambridge University Press.

Dryzek, J. S. (2000) Deliberative Democracy and Beyond. Oxford: Oxford University Press.

Eadson, W. and Foden, M. (2019) State, community and the negotiated construction of energy markets: Community energy policy in England. Geoforum, 100, pp. 21-31.

Fischhoff, B. (1995) Risk Perception and Communication Unplugged: Twenty years of process. Risk Analysis, 15 (2), pp. 137-145.

Giulietti, M., Price C.W. and Waterson, M. (2005) Consumer choice and competition policy: a study of UK energy markets. Economics Journal, 115, pp. 949-968.

Gustafsson, S., Ivner, J. and Palm, J. (2015) Management and stakeholder participation in local strategic energy planning: Examples from Sweden. Journal of Cleaner Production, 98, pp. 205-212.

Habermas, J. (1979) Communication and the Evolution of Society. Translated by Thomas McCarthy. Boston: Beacon Press.

Hargreaves, T. (2011) Practice-ing behaviour change: Applying social practice theory to pro-environmental behaviour change. Journal of Consumer Culture, 11 (1), pp. 7999. Available at: https://doi.org/10.1177/1469540510390500

Hawkey, D., Webb, J. and Winskel, M. (2013) Organisation and governance of urban energy systems: district heating and cooling in the UK. Journal of Cleaner Production, 50 (1), pp. 22-31. Available at: https://doi.org/10.1016/j.jclepro.2012.11.018

Heat and the City (2019) Briefing Note. Edinburgh: Heat and the City, University of Edinburgh. Available at: https://heatandthecity.org.uk/wpcontent/uploads/2019/03/DH-Briefing-note-Final.pdf 
Heat Trust (2018) Annual Report. London: Heat Trust. Available at: https://www.heattrust.org/annual-reports-v2

Helm, D. (2003) Energy, The State, and The Market:British Energy Policy Since 1979. Oxford: Oxford University Press.

House of Commons Library (2018) Briefing paper 05838, neighbourhood planning. London: House of Commons Library.

IEA (2019) Policies of IEA countries: Sweden review2019. Paris, France: International Energy Agency.

Inch, A. (2012) Creating 'a generation of NIMBYs'? Interpreting the role of the state in managing the politics of urban development. Environment and Planning $C, 30$ (3), pp. 520-535.

Irwin, A. (1995) Citizen Science. London: Routledge.

Jackson, T. (2005) Motivating Sustainable Consumption: A review of the evidence on consumer behaviour and behavioural change. A report to the Sustainable Development Research Network. London: Policy Studies Institute.

Jamasb, T. and Pollitt, M. (2005) Electricity market reform in the European Union: review of progress toward liberalization \& integration. The Energy Journal, 26, pp. 1141.

Jasanoff, S. (1993) Bridging the Two Cultures of Risk Analysis. Risk Analysis, 13 (2), pp. 123-129.

Koh, L. and Goucher, L. (2014) Questions around Entry to the UK Energy Supply Market for Small Firms. Sheffield: University of Sheffield.

Lidskog, R. (1997) From Conflict to Communication? Public Participation and Critical Communication as a Solution to Siting Conflicts in Planning for Hazardous Waste. Planning Practice \& Research, 12 (3), pp. 239-249.

Local Energy Scotland (2019) Local energy plans [webpage]. https://www.localenergy.scot/what-is-local-energy/local-energy-plans/

Marres, N. and Lezaun, J. (2011) Materials and devices of the public: an introduction. Economy and Society, 40 (4), pp. 489-509.

May, P.J. (1991) Reconsidering Policy Design: Policies and Publics. Journal of Public Policy, 11 (2), pp. 187-206.

Ofgem (2014) State of the market assessment. London: Ofgem. Available at: https://www.ofgem.gov.uk/sites/default/files/docs/2014/03/assessment document pu blished 1.pdf

Palerm, J.R. (2000) An Empirical-Theoretical Analysis Framework for Public Participation in Environmental Impact Assessment. Journal of Environmental Planning and Management, 43 (5), pp. 581-600.

Palm, J (2007) District Heating as a Secure Heat Supply - A question of regulation. Environment and Energy, 18 (6), pp. 747-760.

Parker, G. (2017) The uneven geographies of neighbourhood planning in England. Bristol: Policy Press: pp. 75-92. 
Pellizzoni, L. (2004) Responsibility and Environmental Governance. Environmental Politics, 13 (3), pp. 541-565.

Petts, J. (1995) Waste Management Strategy Development: A Case Study of Community Involvement and Consensus-Building in Hampshire. Journal of Environmental Planning and Management, 38 (4), pp. 519-536.

Petts, J. (2004) Barriers to Participation and Deliberation in Risk Decisions: Evidence from Waste Management. Journal of Risk Research, 7 (2), pp. 115-133.

Petts, J. and Brooks, C. (2006) Expert Conceptualisations of the role of lay knowledge in environmental decision-making: challenges for deliberative democracy. Environment and Planning A, 38 (6), pp. 1045-1059.

Renn, O. (1992) Risk Communication: Towards a Rational Discourse with the Public. Journal of Hazardous Materials, 29, pp. 465-519.

Royal Town Planning Institute (RTPI) (2019) Planning for a smart energy future. London: RTPI. Available at: https://www.rtpi.org.uk/media/1435/planning-for-a-smartenergy-future.pdf

Rutherford, J. (2014) The Vicissitudes of Energy and Climate Policy in Stockholm: Politics, Materiality and Transition. Urban Studies, 51, pp. 1449-1470.

Scottish Government (2017) Barriers to community engagement in planning: a research study. Edinburgh: Scottish Government. Available at: https://www.gov.scot/binaries/content/documents/govscot/publications/factsheet/201 7/05/barriers-to-community-engagement-in-planning-research/documents/executivesummary-barriers-community-engagement-planning-research-study-pdf/

Scottish Government (2020) Improving public services - community planning [webpage]. Edinburgh: Scottish Government. Available at: https://www.gov.scot/policies/improving-public-services/community-planning/

Shove, E. (2010) Beyond the ABC: climate change and theories of social change. Environment and Planning A, 42, pp. 1273-1285.

Soutar, I. and Mitchell, C. (2018) Towards pragmatic narratives of societal engagement in the UK energy system. Energy Research and Social Science, 35, pp. 132-139.

Sovacool, B. (2014) What are we doing here? Analyzing fifteen years of energy scholarship and proposing a social science research agenda. Energy Research \& Social Science, 1, pp. 1-29.

Staddon, S., Cycil, C., Goulden, M., Leygue, C. and Spence, A. (2016) Intervening to Change Behaviour and Save Energy in the Workplace: A Systematic Review of Available Evidence. Energy Research \& Social Science, 17, pp. 30-51.

Stern, P. (2000) Towards a Coherent Theory of Environmentally Significant Behaviour. Journal of Social Issues, 56 (3), pp. 407-424.

Stern, P. and Fineberg, H. (Eds) (1996) Understanding Risk: Informing Decisions in a Democratic Society. Washington D.C: National Research Council.

UK Government (2019) National Planning Policy Framework 2019. UK Government. Available at: https://assets.publishing.service.gov.uk/government/uploads/system uploads/attachment data/file/810197/NPPF Feb 2019 revised.pdf 
UK Government Department for Business, Energy and Industrial Strategy (BEIS) (2018) Qualitative research with consumers and operators of heat networks. BEIS. Available https://assets.publishing.service.gov.uk/government/uploads/system/uploads/attach ment data/file/762331/heat-network-consumer-operator-experiences.pdf

UK Government Department for Energy and Climate Change (DECC) (2016) Community-led heat projects: a toolkit for heat networks. DECC. Available at: https://s3.eu-west-2.amazonaws.com/prod-wl-

cee/resources/files/Community Heat Networks Toolkit Final 2.1.pdf

UK Government Department of Communities and Local Government (DCLG, 2012) National Planning Practice Guidance. London: DCLG. Available at: https://webarchive.nationalarchives.gov.uk/20120919133846/http://www.communitie s.gov.uk/publications/planningandbuilding/nppf

Van Veelen, B. and Eadson, W. (2019) Assembling community energy democracies. Voluntary Sector Review. DOI: 10.1332/204080519X15740562779512.

Webler, T. (1995). "Right" Discourse in Citizen Participation: An Evaluative Yardstick. In: O. Renn, T. Webler and P. Wiedemann (eds) Fairness \& Competence in Citizen Participation: Evaluating Models for Environmental Discourse. London: Kluwer Academic Publishers: pp. 35-86.

Webler, T. and Tuler, S. (2000) Fairness and competence in citizen participation Theoretical reflections from a case study. Administration \& Society, 32 (5), pp. 566595.

Werner, S. (2017) District heating and cooling in Sweden. Energy, 126, pp. 419-429.

Wills, J. (2016) Emerging geographies of English localism: The case of neighbourhood planning. Political Geography, 53, pp. 43-53. DOI: 10.1016/j.polgeo.2016.02.001.

Wretling, V., Gunnarsson-Östling, U., Hörnberg, C. and Balfors, B. (2018) Strategic municipal energy planning in Sweden - Examining current energy planning practice and its influence on comprehensive planning. Energy Policy, 113, pp. 688-700.

Wynne, B. (1996) May the Sheep Safely Graze. In: S. Lash, B. Szerszynski and B. Wynne (eds) Risk, Environment and Modernity. London: Sage: pp. 44-83.

Yougov (2014) Energy, Politics and the Consumer. Yougov. Available at: http://cdn.yougov.com/cumulus uploads/document/9ex03cskhs/YouGov-CambridgeReportSpring201acc4.pdf

Zakhour, S. (2020) The democratic legitimacy of public participation in planning: Contrasting optimistic, critical, and agnostic understandings. Planning Theory, 1-22 Doi.org/10.1177/1473095219897404. 


\section{Sheffield Hallam University}

Citizen engagement in local energy decision-making: literature and policy background

EADSON, William <http://orcid.org/0000-0002-2158-7205> and BULL, Richard

Available from the Sheffield Hallam University Research Archive (SHURA) at:

http://shura.shu.ac.uk/26499/

\section{Copyright and re-use policy}

Please visit http://shura.shu.ac.uk/26499/ and http://shura.shu.ac.uk/information.html for further details about copyright and re-use permissions. 